\title{
The Wrecked Temple in Me (Vo mne zbúraný chrám)
}

\author{
Author: Milan Richter
}

First Published: 2002

Translations: selected pieces in English and German (Vo mne zbúraný chrám: The Wrecked Temple in Me: Der niedergerissene Tempel in mir, 2002).

About the Author: Milan Richter (1948) was born into a Slovak-Czech-Jewish family in Bratislava. His parents had survived the Holocaust, nevertheless, his grandparents and aunts perished in concentration camps in Poland. Richter studied German and English at Comenius University in Bratislava. He worked in publishing houses and translated from English, German, Swedish and other languages (Ernest Hemingway's poems, J. W. Goethe's Faust, the theatre adaptation of which was premiered in Bratislava 2010, Franz Kafka's aphorisms, R. M. Rilke's poems among others). In the 1990s, he was the Slovakian chargé d'affaires in Norway and an editor in literary reviews and later in his own publishing house MilaniuM. He compiled the first anthology of Slovak literature about the Holocaust God's Lane (1998, Božia ulička). He published several collections of poems and is an author of several plays and radio plays, for instance the docudrama Alfréd Wetzler, A Hero Against His Will (2018, Nechcený hrdina Alfréd Wetzler).

Further Important Publications: Korene vo vzduchu (1992, Roots in the Air; poems); Spoza zamatových opôn (1997, From Behind the Velvet Curtains; poems); Anjel s čiernym perim (2000, An Angel with Black Feathers; poems); Tajomstvá dokorán (2008, Secrets Wide Open; poems).

\section{Content and Interpretation}

The collection contains 33 poems, 11 of them also in English translations and 7 of them in German translations. In the majority of cases, they have been published in Richter's previous books, some of them are new. The poems are followed by explanations where the author clarifies historical and personal context, to which the texts refer. The book also contains a short testimony from Erika Richterová, born Grimm, the author's mother, about her internment in ghettos.

Almost all the texts present stories from the traditional Jewish past, especially from the Holocaust. Three poems evoke heroic characters from the Hebrew Bible (Old Testament) (Moses; Esther and three young men in the blazing furnace). The author's relatives appear in many of the poems, so do his grandmother, father, aunts, uncle, cousin and nieces. But particular attention is paid to the author's mother. The first part of the poem Hopes (Nádeje), with the subtitle February 1939, presents his mother as a young girl before the war and the persecution of her family. 


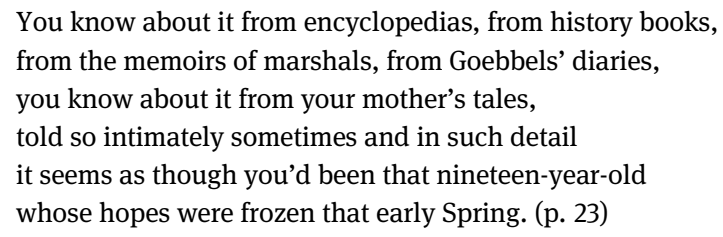

In Three Lives (Tri životy) it is noted that she had escaped death three times when she was excluded from the transports to Auschwitz. Nevertheless, her parents and other people close to her have died. The poem Meeting in the Courtyard of Death (Stretnutie na nádvorí smrti) describes the first meeting of his mother and his father in Theresienstadt in October 1944.

Other poems also thematise the motifs of the Shoah. Roots in the Air (Korene vo vzduchu) utilises the motto of the world-known German-Jewish poet Paul Celan "In the air, that's where your roots are, / over there, in the air". It's the dialogue of two neighbours probably held on the Day of the Dead Honoring the Deceased. The first man had visited graves of his mother, brother etc. The second is running home. The neighbour asks "You've been to your graves then?" he answers: "I have no graves... [...] In the air about Auschwitz, over there, / in the air they lie" (p. 16).

The last and title poem The Wrecked Temple in Me (Vo mne zbúraný chrám) connects the history of Jews and the author's family history with the Holocaust. The author brings to mind the suffering of Joseph, thrown in the pit, the tribulation of Daniel and other Jewish figures. He recalls his grandfathers, the war and the harsh postwar fate of the Jews:

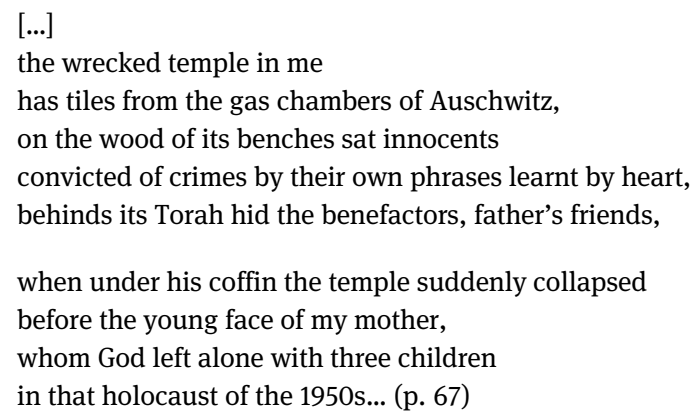

The verse "holocaust of the 1950" is more comprehensible from the afore mentioned poem Meeting in the Courtyard of Death (Stretnutie na nádvorí smrti). Here, the author writes "the creeping Holocaust... did not drop in the camps, it settled like a louse / in the leather coats of informers, guardsmen, in the skin of the communists" (p. 37).

\section{Main Topics and Problems}

Most poems are written in free verse and are epic, based on a story or event, with the author's comments and reflections. The author presents the Holocaust as a part of his 
family history, but also as a part of Jewish history in general. According to him, the Holocaust is not something divergent and singular in history; it is only the event where the persecution of Jews continues and culminates here. So the author is inclined to stress a universal and collective representation of the Shoah. This corresponds to the symbol of the wrecked temple in the title. The author tries to "build quietly this temple" again (p. 87), but the contemporary world "that gives no joy / to those who do not shout and destroy" (p. 87) does not have a positive response to it.

The Holocaust, which was based on xenophobia and hatred, did not end with the defeat of Nazism. Even into the present, it has continued to reemerge in old as well as in new forms.

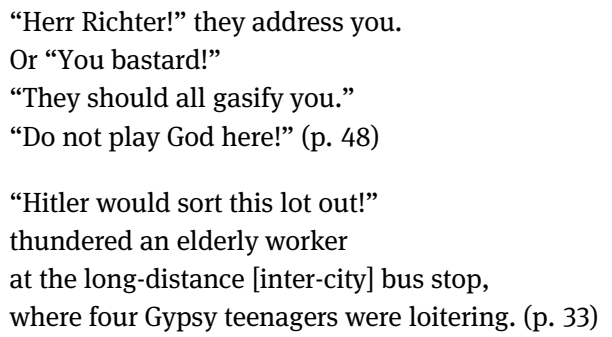

Some poems respond to current events or documents. For instance, Small Jewish Blackboard (Malá židovská tabul'a) replies to revealing the memorial plaque of the President of the Slovak clerofascist regime Jozef Tiso in the summer of 1990. He was responsible for the persecution and deportations of Slovak Jews. Tiso was executed in 1947 for war crimes and crimes against humanity. The author is reminded of his relatives whom Tiso and his government had sent to death and of the fact that the Slovak government had paid Hitler's Germany 500 marks for each Jew sent to a concentration camp in Poland.

In The Wrecked Temple in Me, many traditional motifs can be found which are common for Holocaust literature, i.e. a vision of God "who walked off in the gas / in the smoke of his children” (p. 51). It is similar to Ota B. Kraus's vision $\rightarrow$ The Land without God or Otto Weiss's story $\rightarrow$ And God Saw That It Was Bad where God can only helplessly watch the events in the Theresienstadt Ghetto. Another frequently used motif in Holocaust literature is a surviving trauma that is thematised here in the poem The One Who Survived (Ten, ktorý prežil). References to the Hebrew Bible (Old Testament) that recall the current situation of the Jews, are also often found (see afore). For example, in the poem At the Time of Leaving (Vo chvíli odchádzania), the author paraphrases The Book of Ecclesiastes (Kohelet) as well as the Song of Songs.

\section{Cited Work}

Richter, M. (2002). Vo mne zbúraný chrám. The Wrecked Temple in Me. Der niedergerissene Tempel in mir. Dunajská Lužná: MilaniuM. 


\section{Further References}

Kochol, V. (1979). Literárne reflexie. Bratislava: Slovenský spisovatel', pp. 338-345. Štroblová, J. (2002).V nejkřestanštějším ze všech světů jsou básníci židi. In: M. Richter, Vo mne zbưraný chrám. Dunajská Lužná: MilaniuM, pp. 7-9. 
